Pesq. Vet. Bras. 36(9):811-818, setembro 2016 DOI: $10.1590 / \mathrm{S} 0100-736 \mathrm{X} 2016000900004$

\title{
Somatic cell count and mastitis pathogen detection in composite and single or duplicate quarter milk samples ${ }^{1}$
}

\author{
Fernando N. Souza ${ }^{2 *}$, Adriano F. Cunha ${ }^{2}$, Dalila L.S.O. Rosa ${ }^{3}$, Maria Aparecida \\ V. Brito ${ }^{4}$, Alessandro S. Guimarães ${ }^{4,5}$, Letícia C. Mendonça ${ }^{4}$, Guilherme N. \\ Souza $^{4}$, Andrey P. Lage ${ }^{2}$, Maiara G. Blagitz ${ }^{6}$, Alice M.M.P. Della Libera ${ }^{6}$, Marcos B. \\ Heinemann $^{7}$ and Mônica M.O.P. Cerqueira ${ }^{3}$
}

\begin{abstract}
Souza F.N., Cunha A.F., Rosa D.L.S.O., Brito M.A.V., Guimarães A.S., Mendonça L.C., Souza G.N., Lage A.P., Blagitz M.G., Della Libera A.M.M.P., Heinemann M.B. \& Cerqueira M.M.O.P. 2016. Somatic cell count and mastitis pathogen detection in composite and single or duplicate quarter milk samples. Pesquisa Veterinária Brasileira 36(9):811-818. Departamento de Medicina Veterinária Preventiva, Escola de Veterinária, Universidade Federal de Minas Gerais, Av. Presidente Antônio Carlos 6627, Belo Horizonte, MG 31270-910, Brazil. E-mail: nogueirasouza@yahoo.com.br

The most acceptable criteria for diagnosing bovine intramammary infections include results of bacteriological culture and measures of inflammation. Therefore, information on the diagnostic characteristics of the procedures used to identify infected quarters is required. Thus, this study was designed to evaluate a set of criteria to classify the infectious status of an udder at the quarter (single and duplicate milk samples) and cow (composite milk sample) levels, and to compare the infectious status with somatic cell counts (SCCs) of the samples. Here, the SCC thresholds determined by receiver operating characteristic curve analysis had a higher Youden index using mammary quarter duplicate milk samples as the gold standard for testing compared with single quarter and composite milk samples, especially for samples for which at least one of the duplicates was microbiologically positive, regardless of the mastitis pathogen isolated. The kappa coefficient for bacteriological results of the single quarter milk samples (single S1 and S2) was $0.85 \pm 0.019$, indicating that single quarter milk sampling can be useful in mastitis control programs. Therefore, the use of composite milk samples to detect mastitis pathogens may be limited to the detection of major pathogens, given their predictive values. Thus, our findings suggest that the milk SCCs and microbiological examinations, although regarded as the most reliable indicators of ongoing mastitis, should be used in an integrated manner in mastitis control programs. Furthermore, the accuracy of single, duplicate and composite microbiological analyses to diagnosis mastitis should be considered for its implications in mastitis control strategies.
\end{abstract}

INDEX TERMS: Somatic cell count, mastitis, intramammary infection, sensitivity, specificity, udder health status, dairy cow.

\footnotetext{
${ }^{1}$ Received on October 17, 2015.

Accepted for publication on June 20, 2016.

Part of the thesis of the first author submitted to the Post-Graduate Program in Animal Science of the Veterinary School, Universidade Federal de Minas Gerais.

${ }^{2}$ Departamento de Medicina Veterinária Preventiva, Escola de Veterinária, Universidade Federal de Minas Gerais (UFMG), Av. Presidente Antônio Carlos 6627, Belo Horizonte, MG 31270-910, Brazil. *Corresponding author: nogueirasouza@yahoo.com.br

${ }^{3}$ Departamento de Tecnologia e Inspeção de Produtos de Origem Animal, Escola de Veterinária, UFMG, Av. Presidente Antônio Carlos 6627, Belo Horizonte, MG 31270-910, Brazil
}

\footnotetext{
${ }^{4}$ Embrapa Gado de Leite, Av. Eugênio do Nascimento 610, Juiz de Fora, MG 36038-330, Brazil.

${ }^{5}$ Departamento de Medicina Veterinária, Universidade Federal de Lavras (UFLA), Campus Universitário, Caixa Postal 3037 Lavras, MG 37200000 , Brazil.

${ }^{6}$ Departamento de Clínica Médica, Faculdade de Medicina Veterinária e Zootecnia (FMVZ), Universidade de São Paulo (USP), Av. Prof. Dr. Orlando Marques de Paiva 87, Cidade Universitária, São Paulo, SP 05508-270, Brazil.

${ }^{7}$ Departamento de Medicina Veterinária Preventiva e Saúde Animal, FMVZ/USP, Av. Prof. Dr. Orlando Marques de Paiva 87, Cidade Universitária, São Paulo, SP 05508-270, Brazil.
} 
RESUMO.- [Contagem de células somáticas e detecção de patógenos causadores de mastite em amostras de leite compostas e individuais simples ou em duplicata.] Os critérios mais aceitáveis para o diagnóstico das infecções intramamárias em bovinos incluem tanto os resultados da cultura bacteriológica e dos indicadores de inflamação. Portanto, a informação sobre os procedimentos mais adequados a serem utilizados para identificação dos quartos infectados é necessária. Assim, o objetivo do presente estudo foi avaliar um conjunto de critérios para identificação da infecção intramamária em bovinos pelo exame microbiológico (amostras individuais de leite simples ou em duplicata, e amostras de leite compostas), e comparar o isolamento do patógeno nas amostras de leite coletadas por distintos critérios com a contagem de células somáticas (CCS). Os valores de corte da CCS determinados pela curva de característica de operação do receptor demonstraram que a coleta de amostras de leite em duplicata apresentou o maior valor do índice de Youden, especialmente quando considerou-se o quarto mamário infectado se pelo menos uma das amostras de leite da duplicata apresentou resultado bacteriológico positivo independentemente do patógeno isolado. 0 coeficiente kappa dos resultados do exame microbiológico das amostras de leite individuais (amostra simples S1 e S2) foi de $0,85 \pm 0,019$, indicando que a coleta de amostras de leite individual, ou seja, a coleta de uma amostra de leite por quarto mamário, pode ser utilizada nos programas de controle de mastite. Por outro lado, a coleta de amostras de leite compostas para detectar patógenos causadores de mastite deve ser limitada à detecção dos patógenos principais, considerando os valores preditivos encontrados no presente estudo. Portanto, os resultados do presente estudo indicam que a CCS e o exame microbiológico do leite, embora considerados como os critérios mais aceitos para o diagnóstico da mastite, devem ser utilizados de forma integrada em programas de controle de mastite. Além disto, os critérios de coleta de amostras de leite para o diagnóstico da mastite pelo exame microbiológico e seus valores preditivos devem ser considerados nos programas de controle de mastite.

TERMOS DE INDEXAÇ̃̃O: Contagem de células somáticas, mastite, infecção intramamária, sensibilidade, especificidade, saúde da glândula mamária, vaca leiteira.

\section{INTRODUCTION}

Worldwide, mastitis is the most common infectious disease affecting dairy cows and the most economically important disease in the dairy industry (Halasa et al. 2007). Mastitis refers to inflammation within the udder but not necessarily infection; however, mastitis is usually caused by a bacterial infection (Pyörälä 2003, Dohoo et al. 2011a, Dohoo et al. 2011b, Reyher \& Dohoo 2011, Oliveira et al. 2013). Given the central role of intramammary infections (IMIs) in bovine mastitis, high-quality information on the test characteristics of the procedures used to identify infected quarters is required (Dohoo et al. 2011a, 2011b, Reyher \& Dohoo 2011).

Information considered in the guidelines for diagnosing mastitis include both results of microbiological culture and measurements of inflammation, in addition to discussion regarding the number of samples that should be tested to maximize sensitivity and specificity parameters (Dohoo et al. 2011a). Thus, the use of composite, single, duplicate or triplicate milk samples can affect the predictive values of microbiological culture (Dohoo et al. 2011a, 2011b, Reyher \& Dohoo 2011), which is the most expensive component of diagnosing IMI. Then, in an attempt to minimize costs, a relevant question is whether composite milk sampling, or at least individual quarter milk sampling, would be useful for detecting culture-positive milk samples.

Furthermore, the milk somatic cell count (SCC) has been extensively used as an indicator of IMI; the SCC is included as a component of the definition of mastitis, as the milk SCC markedly increases during infection (Pyörälä 2003, Schukken et al. 2003, Della Libera et al. 2011, Dufour \& Dohoo 2013). Altogether, we hypothesized that isolation of the infection agent affect the SCC thresholds used to detect infected quarters or cows, as microbiological culture has long been considered the gold standard test compared with other mastitis diagnostic tests (Pyörälä 2003).

Thus, this study was designed to evaluate a set of criteria used for classifying infection, accounting for the microbiological status of an udder at the quarter (single and duplicate milk samples) and cow (composite milk sample) levels and to compare the infectious status with the SCC (at the quarter and cow levels).

\section{MATERIALS AND METHODS}

Herd(s). Data were collected from 36 dairy cows from January 2013 to January 2014 in two dairy herds from Minas Gerais State, Brazil. Both herds had high bulk milk SCCs ( $>500,000$ cells/ $\mathrm{mL}$ ) according to the criteria proposed by Barkema et al. (1998). All Holstein dairy cows were milked twice daily, and yielded an average of $16.68 \pm 0.97$ (herd 1) and $23.86 \pm 1.30$ (herd 2) kg milk/ day. No samples from dairy cows immediately post-partum (before the fifth day after calving) were used. The herds underwent machine milking, and the following mastitis control practices for milking were adopted: forestripping in a strip cup to check for clinical mastitis, pre-dipping, and drying teats with a paper towel. After milking, post-dipping was also used. Dry cow therapy and clinical mastitis treatments were also adopted. As both herds contained cows with Staphylococcus aureus mastitis, the cows identified as infected by this pathogen were segregated from the milking line and were milked last. This research complied with the Ethical Principles for Animal Research and was approved by the Bioethics Commission of the Universidade Federal de Minas Gerais (Protocol n. 211/2011).

Experiment 1. Data from 1,600 microbiological milk cultures and 800 SCCs were recorded. Duplicate quarter milk samples (two samples collected at the same milking) were collected from all quarters ( $\mathrm{n}=800$ quarters) (referred to as samples S1 and S2) for microbiological examination. Individual quarter milk samples were also collected for SCC evaluations. Duplicate quarter milk samples were categorized as A or B, as follows. (A) First, when the same pathogen was isolated from both samples, the sample was regarded as microbiologically positive for that microorganism. Nevertheless, if a pathogen was recovered only in one pair of the duplicate, the quarter was considered as non-infected according to the microbiological results and was considered to display non-significant growth, except in the case of $S$. aureus or Streptococcus 
agalactiae infection. This exception was applied for S. agalactiae because it is regarded as a highly contagious obligate parasite of the bovine mammary gland (Keefe 1997) and for S. aureus due to its peculiar shedding pattern, particularly because the shedding pattern could be below the detection limit of the microbiological method employed (Sears et al. 1990, Zecconi et al. 1997, Godden et al. 2002, Walker et al. 2010). (B) Second, the milk sample was regarded as microbiologically positive if at least one of the duplicate samples (single S1 or S2) was microbiologically positive regardless of which mastitis pathogen was isolated.

Experiment 2. Data from 1,215 microbiological milk cultures and 135 SCCs were recorded. The data were collected from January to June 2013 in herd 1. Duplicate quarter milk samples (two samples collected at the same milking) were collected from all quarters ( $\mathrm{n}=540$ quarters), and then composite milk samples for microbiological analysis were collected. Composite milk samples for SCCs $(n=135)$ were collected through milk meters. Samples yielding colonies of $\geq 3$ different bacterial species in the microbiological analysis were considered to be contaminated. The quarter was considered to be non-infected when a pathogen was not recovered in at least one pair of the duplicate, or when one sample of the duplicate quarter milk samples was microbiologically negative and the other one was contaminated. If a cow had an IMI caused by a particular organism according to the criteria described above for duplicate quarter milk samples (criteria B) in at least one quarter, the cow was considered positive for that organism.

Sampling. First, the strip cup test was performed to determine the presence of clots or flakes or otherwise obviously abnormal secretions. Then, pre-dipping was performed, and one towel was used for each teat. After discarding the first three milk strea$\mathrm{ms}$, the ends of the teats were scrubbed with $70 \%$ ethanol using cotton balls, and foremilk duplicate milk samples from the individual mammary quarters (approximately $4 \mathrm{~mL}$ in each vial) and composite milk samples (approximately $40 \mathrm{~mL}$ ) were aseptically collected in sterile vials for microbiological analysis. Finally, quarter milk samples for SCCs were collected. Composite milk samples for SCCs were collected through milk meters, as routinely used in Dairy Herd Improvement (DHI) programs for monitoring the SCCs of individual cows (Ruegg \& Pantoja 2013).

All samples for microbiological analysis were frozen at $-20 \stackrel{\circ}{ } \mathrm{C}$ for a maximum of 30 days until cultured. Both samples, referred to as S1 and S2, from duplicate milk samples were individually considered to analyze the predictive values of single milk samples.

Microbiological analysis. Bacterial analysis was conducted by culturing $0.01 \mathrm{~mL}$ of each sample on $5 \%$ ovine blood agar plates. The plates were incubated for $24-48$ hours at $37^{\circ} \mathrm{C}$; then, colony morphology was observed and Gram staining and identification tests were conducted (Brito et al. 1999, Oliver et al. 2004). The microorganisms were identified from subcultures on plates containing Brain Heart Infusion agar. The Gram-positive, catalase-negative cocci were identified by the production of CAMP factor and pyrrolydonylarylamidase (assessed by the PYR test), the hydrolysis of sodium hippurate and esculin, and growth in $6.5 \%$ $\mathrm{NaCl}$ broth and on bile-esculin agar. S. agalactiae, S. uberis, S. equinus and Enterococcus spp. could be differentiated using this set of tests. The streptococci-like organisms that could not be identified were classified as Streptococcus spp. The Gram-positive, catalase-positive cocci were identified as coagulase-negative staphylococci and coagulase-positive staphylococci by means of tube coagulase tests. Among the coagulase-positive staphylococci, Staphylococcus aureus was identified based on a positive acetoin test (Voges-Proskauer test) (Oliver et al. 2004), the coagulase-positive staphylococci negative in the Voges-Proskauer test was regarded as coagulase-positive staphylococci (other than S. aureus). Gram- -negative bacteria were differentiated based on their appearance on MacConkey's agar, reactions with Triple Sugar Iron agar, indol production, motility, citrate utilization, the oxidative-fermentative test (Hugh \& Leifson medium), the methyl red reaction and acetoin production. Gram-positive, catalase-positive, non-hemolytic, rod-shaped bacteria with typical morphology of coryneforms visible only after 48 hours of incubation mainly in the fatty areas on milk-streaked plates were classified as Corynebacterium spp. In the analysis, these bacteria were considered as Corynebacterium bovis. A milk sample from which three or more different species were cultured was considered contaminated (Oliver et al. 2004). Sample sets with contamination in one of the single milk samples (S1 or S2) were excluded from all analyses.

Somatic cell counts. Composite and quarter milk samples for SCCs were collected in a $40-\mathrm{mL}$ vial containing microtablets of bronopol (2-bromo-2-nitropane-1,3-diol) and were analyzed using a calibrated Bentley CombSystem 2300 unit (Chaska, USA).

IMI definition. A quarter was defined as having an IMI if $\geq$ 300 colony forming unit colony/mL were detected in the microbiological culture, except for $S$. aureus or $S$. agalactiae, which were considered as culture-positive when the growth of $\geq 100$ colony forming unit colony/mL was detected, and Corynebacterium sp., which was regarded as microbiological positive when $\geq 1,000$ colony forming unit colony/mL grew in the culture (Andersen et al. 2010).

Statistical analysis. All statistical analyses to determine the diagnostic characteristics of the tests (kappa coefficient, area under the receiver operating characteristic (ROC) curve, sensitivity, specificity, Youden index, positive and negative likelihood ratios, and positive and negative predictive values) were performed using Meldcalc statistical software (Meldcalc software, Belgium). Two SCC thresholds (100 and $200 \times 10^{3}$ cells $/ \mathrm{mL}$ ) and one SCC threshold $\left(200 \times 10^{3}\right.$ cells $\left./ \mathrm{mL}\right)$ were used to determine the sensitivity and specificity of individual mammary quarter and udder (composite) samples, respectively, using the microbiological results as the gold standard test. The microbiological results of the duplicate quarter milk sample with the highest Youden index according to the previously described criteria (A or B) were considered as the reference to define the presence of IMIs and were used to evaluate the predictive values of the composite SCC results. The distributions of the SCC data were examined using normal probability plots obtained using the Shapiro-Wilk test. As the SCC data were nonparametric, even when log transformed, the Kruskal-Wallis and Mann-Whitney tests were applied. The variations of the SCCs according to the microbiological results were analyzed using GraphPad Prism 5.0 software ${ }^{\circledR}$ (GraphPad Software, Inc., San Diego, CA, USA). Significance was set at $P \leq 0.05$.

\section{RESULTS}

\section{Experiment 1}

The distribution of microorganisms isolated from quarter milk samples is shown in Table 1 . The area under the ROC curve and the predictive values of the milk quarter SCC regarding the SCC threshold that maximized the sensitivity and specificity, indicated by the ROC curve analysis and the most used SCC thresholds $(100,000$ and 200,000 cells/ $\mathrm{mL}$ ) to detect IMIs, are shown in Table 2. Here, $13.26 \%$ (criteria A) and $8.74 \%$ (criteria B) of the duplicate quarter milk samples were microbiologically positive with very low SCCs ( $\leq 100,000$ cell $/ \mathrm{mL}$ ), and $17.17 \%$ (under criteria A) and $18.43 \%$ (under criteria B) of the duplicate quarter milk samples were microbiologically negative with high SCCs $(>200,000$ cells $/ \mathrm{mL})$. The milk quarter SCCs according 
to the different pathogens isolated are shown in Table 3. The kappa coefficient between the single (S1 and S2) milk quarter microbiological results (single S1 and S2) was 0.85 (95\% confidence interval 0.813-0.886).

\section{Experiment 2}

The distribution of microorganisms isolated from the composite milk samples is presented in Table 4. The area under the ROC curve and the predictive values of the com-

Table 1. Bacteriological results of the single milk quarter samples

\begin{tabular}{lcc}
\hline Bacteriological results & Single S1(n=800) & Single S2(n=800) \\
\hline No growth & $52.12 \%(417)$ & $53.38 \%(427)$ \\
S. aureus & $16.88 \%(135)$ & $16.25 \%(130)$ \\
S. agalactiae & $7.25 \%(58)$ & $7.50 \%(60)$ \\
Corynebacterium bovis & $5.00 \%(40)$ & $4.63 \%(37)$ \\
S. uberis & $4.63 \%(37)$ & $4.25 \%(34)$ \\
Streptococcus spp. & $1.50 \%(12)$ & $1.37 \%(11)$ \\
CoPS & $0.88 \%(7)$ & $1.37 \%(11)$ \\
CoNS & $1.00 \%(8)$ & $0.87 \%(7)$ \\
E. coli & $0.12 \%(1)$ & $0.12 \%(1)$ \\
S. equinus & $0.12 \%(1)$ & $0 \%(0)$ \\
S. aureus and S. agalactiae & $7.50 \%(60)$ & $7.13 \%(57)$ \\
S. aureus and S. uberis & $1.38 \%(11)$ & $1.12 \%(9)$ \\
S. aureus and Streptococcus spp. & $0.25 \%(2)$ & $0.63 \%(5)$ \\
S. aureus and Enterococcus spp. & $0.38 \%(3)$ & $0.25 \%(2)$ \\
S. aureus and Corynebacterium bovis & $0.25 \%(2)$ & $0.38 \%(3)$ \\
S. uberis and CoNS & $0.12 \%(1)$ & $0.25 \%(2)$ \\
S. aureus e S. equinus & $0.38 \%(3)$ & $0.38 \%(3)$ \\
CoNS and Streptococcus spp. & $0.12 \%(1)$ & $0.12 \%(1)$ \\
CoNS and S. agalactiae & $0.12 \%(1)$ & $0(0 \%)$ \\
S. &
\end{tabular}

S. aureus = Staphylococcus aureus; S. agalactiae = Streptococcus agalac tiae; S. uberis = Streptococcus uberis; Streptococcus spp. = Streptococcus spp. excluding S. agalactiae, S. equinus, S. uberis, and Enterococcus sp.; CoPS = coagulase-positive staphylococci other than S. aureus; CoNS = coagulase-negative staphylococci; E. coli = Escherichia coli; $S$. equinus = Streptococcus equinus. posite SCC regarding the SCC threshold that maximized the sensitivity and specificity, indicated by the ROC curve analysis and the most used SCC cut-off $(200,000$ cells/mL) to detect IMIs, are shown in Table 5. The composite SCCs of the microbiologically positive and negative milk samples are presented in Table 6. The composite SCCs according to the different pathogens are shown in Table 7. The accuracy of the microbiological composite milk samples, using the results of the duplicate milk samples as the gold standard, is presented in Table 8.

\section{DISCUSSION}

In the present study, the duplicate milk quarter samples were regarded as microbiologically positive if at least one of the duplicate samples was microbiologically positive, regardless of whether the mastitis pathogen isolated (criteria B) had a higher Youden index (Table 2); as a result, duplicate samples were considered here as the gold standard for testing to diagnosis mastitis. The Youden index indicates the performance of a diagnostic test, and its value ranges from zero to one. A value of zero indicates that a diagnostic test provided the same proportion of positive results for groups with and without the disease, and a value of one indicates that no false positives or false negatives were detected (Schisterman et al. 2005). Notably, however, isolation of the etiological agent in mastitis might not be possible for several reasons: microorganisms may be excreted intermittently and in small amounts; the infection-related pathogens might not be detectable using conventional microbiological tests; some milk enzymes or proteins (i.e., lysozymes and lactoferrin) may thwart pathogen detection; and the infection might be supported by bacterial endotoxins and bio-active compounds released by neutrophils that might remain following elimination of the

Table 2. The ROC curve and sensitivity/specificity of the quarter milk SCCs considering the single and duplicate bacteriological sampling results as a gold standard

\begin{tabular}{|c|c|c|c|c|}
\hline \multirow{2}{*}{$\begin{array}{c}\text { Predictive values/ } \\
\text { bacteriological sampling }\end{array}$} & Single (S1) & Single (S2) & Duplicate $^{\mathrm{a}}$ & Duplicate $^{\mathrm{b}}$ \\
\hline & \multicolumn{4}{|c|}{ Receiver operating characteristics (ROC) analysis } \\
\hline Area under ROC curve $(95 \% \mathrm{CI})$ & $0.879(0.854-0.901)$ & $0.890(0.865-0.911)$ & $0.897(0.873-0.917)$ & $0.883(0.859-0.905)$ \\
\hline${ }^{\mathrm{P}}$ value & $<0.0001$ & $<0.0001$ & $<0.0001$ & $<0.0001$ \\
\hline SCC Threshold (cells/mL) & 266,000 & 266,000 & 266,000 & 272,000 \\
\hline Youden index & 0.679 & 0.696 & 0.710 & 0.883 \\
\hline Sensitivity $(95 \% \mathrm{CI})$ & $83.2(79.9-86.8)$ & $85.0(80.9-88.6)$ & $85.2(81.1-88.6)$ & $81.7(77.5-85.4)$ \\
\hline \multirow[t]{2}{*}{ Specificity $(95 \% \mathrm{CI})$} & $84.7(80.8-88.1)$ & $84.6(80.7-87.9)$ & $85.9(82.1-89.1)$ & $86.5(82.7$ - 89.8) \\
\hline & \multicolumn{4}{|c|}{ Established threshold values } \\
\hline \multicolumn{5}{|l|}{200,000 cells $/ \mathrm{mL}$} \\
\hline $\begin{array}{l}\text { Sensitivity }(95 \% \mathrm{CI}) \\
200,000 \text { cells } / \mathrm{mL}\end{array}$ & $85.3(81.3-88.7)$ & $87.5(83.7-90.8)$ & $87.6(83.9-90.8)$ & $84.5(80.5-88.0)$ \\
\hline Specificity $(95 \% \mathrm{CI})$ & $81.2(77.0-84.9)$ & $81.4(77.2-85.0)$ & $82.6(78.6-86.2)$ & $82.6(78.5-86.3)$ \\
\hline \multicolumn{5}{|l|}{100,000 cells $/ \mathrm{mL}$} \\
\hline Sensitivity $(95 \% \mathrm{CI})$ & $90.4(86.9$ - 93.2) & $92.0(88.7$ - 94.6) & 91.9 (88.7 - 94.5) & 89.7 (86.2 - 92.5) \\
\hline \multicolumn{5}{|l|}{100,000 cells $/ \mathrm{mL}$} \\
\hline Specificity $(95 \% \mathrm{CI})$ & $67.9(63.1-72.5)$ & $68.1(63.4-72.6)$ & $69.0(64.2-73.5)$ & $69.4(64.6-74.0)$ \\
\hline
\end{tabular}


Table 3. The median (mean+SEM) milk quarter SCC (cells/mL) in quarters infected by distinct mastitis pathogens

\begin{tabular}{|c|c|c|c|c|}
\hline $\begin{array}{l}\text { Bacteriological } \\
\text { results }\end{array}$ & Single (S1) & Single (S2) & Duplicate $^{\mathrm{a}}$ & Duplicate $^{\mathrm{b}}$ \\
\hline No growth & $45,000(251,489+36,805)^{\mathrm{c}}$ & $44,000(241,184+33,104)^{\mathrm{b}}$ & $44,000(223,421+31,953)^{\mathrm{b}}$ & $38,500(226,464+33,702)^{\mathrm{b}}$ \\
\hline Positive & $824,000(1,313,051+72,304)^{a}$ & $837,000(1,352,861+75,450)^{a}$ & $858,000(1,371,721+74,482)^{\mathrm{a}}$ & $795,000(1,300,807+71,600)^{\mathrm{a}}$ \\
\hline CoPS & $484,000(1,149,000+701,468)^{\mathrm{ab}}$ & $557,000(941,546+445,986)^{\mathrm{ab}}$ & $484,000(1,149,000+701,468)^{\mathrm{ab}}$ & $484,000(975,556+550,531)^{\mathrm{ab}}$ \\
\hline $\begin{array}{l}\text { Corynebacterium } \\
\text { bovis }\end{array}$ & $88,500(390,583+178,925)^{\mathrm{bc}}$ & $90,000(416,000+194,718)^{b}$ & $88,500(452,038+244,908)^{b}$ & $87,000(370,538+165,523)^{b}$ \\
\hline Streptococcus spp. & $500,000(685,545+248,613)^{\mathrm{abc}}$ & $524,000(827,444+283,851)^{\mathrm{ab}}$ & $524,000(827,444+283,851)^{\mathrm{ab}}$ & $500,000(685,545+248,613)^{\mathrm{ab}}$ \\
\hline S. uberis & $803,500(1,294,778+235,249)^{a}$ & $803,500(1,314,794+244,469)^{\mathrm{a}}$ & $956,500(1,380,281+255,423)^{a}$ & $705,000(1,270,743+241,179)^{a}$ \\
\hline $\begin{array}{l}\text { S. aureus and } \\
\text { S. agalactiae }\end{array}$ & $1,024,500(1,964,817+242,727)^{a}$ & $1,024,500(1,957,839+246,219)^{a}$ & $1,023,000(1,901,333+233,877)^{a}$ & $1,023,000(1,901,333+233,877)^{\mathrm{a}}$ \\
\hline $\begin{array}{l}\text { S. aureus and } \\
\text { S. uberis }\end{array}$ & $1,169,000(1,634,091+276,654)^{a}$ & $1,169,000(1,384,556+310,507)^{a}$ & $1,317,500(1,732,900+429,550)^{a}$ & $1,317,500(1,702,400+440,366)^{a}$ \\
\hline
\end{tabular}

invading bacteria. Moreover, some bacteria may be present in the teat canal without causing significant inflammation, and others may be present as contaminants (Pyörälä 2003, Nunes et al. 2008). Accordingly, some authors have isolated mastitis pathogens from milk samples with very low SCCs, whereas others have found high proportions of microbiologically negative milk samples with high SCCs (Makovec \& Ruegg 2003, Koskinen et al. 2009, Oliveira et al. 2013), as found in this study. Therefore, one problem regarding the diagnosis of mastitis is that indirect tests are compared with the "golden standard" of bacteriology, although mastitis does not always require the presence of infection (Pyörälä 2003, Nunes et al. 2008).

A high agreement between the microbiological analyses of the single milk quarters (single S1 and S2) samples (kappa coefficient $=0.85$ ) was found in this study. Thus, the use of single quarter microbiological sampling appears to be acceptable in mastitis control programs, especially if the costs of microbiological sampling are taken into account. In addition, the SCC thresholds found in this study for single and duplicate milk samples by ROC curve analysis were similar (Table 2).

When evaluating data on udder infections, it is important to keep in mind that cows live in environments with a high exposure to microorganisms and that not all contacts result in IMIs. Because of the SCC-mediated defense mechanisms of the mammary glands against invading pathogens and dairy cows used in the present study are under high challenge (bulk milk tank > 250,000 cells/mL; Barkema et al. 1998), we hypothesized that these facts, together with the dynamic nature of IMIs due to the contagious nature of many mastitis pathogens, explain why high SCC thresholds indicated by ROC curve analysis were found here (Table 5). These facts may account for the high SCC threshold encountered here compared with the SCC thresholds frequently suggested by other studies from many countries that have implemented effective mastitis control progra-
Table 4. The bacteriological results of composite (at cow level) and duplicateb (at quarter level) milk samples

\begin{tabular}{lcc}
\hline Bacteriological results & $\begin{array}{c}\text { Cow level } \\
(\mathrm{n}=135)\end{array}$ & $\begin{array}{c}\text { Quarter level } \\
(\mathrm{n}=540)\end{array}$ \\
\hline No growth & $43.70 \%(59)$ & $61.85 \%(334)$ \\
S. aureus & $15.56 \%(21)$ & $13.33 \%(72)$ \\
S. uberis & $7.41 \%(10)$ & $6.85 \%(37)$ \\
CoPS & $5.19 \%(7)$ & $0.93 \%(5)$ \\
CoNS & $4.44 \%(6)$ & $3.52 \%(19)$ \\
Corynebacterium bovis & $4.44 \%(6)$ & $7.96 \%(43)$ \\
Streptococcus spp. & $1.48 \%(2)$ & $0.93 \%(5)$ \\
S. agalactiae & $0 \%(0)$ & $0.37 \%(2)$ \\
E. coli & $0 \%(0)$ & $0.19 \%(1)$ \\
S. aureus and S. uberis & $8.15 \%(11)$ & $1.48 \%(8)$ \\
S. aureus and S. agalactiae & $1.48 \%(2)$ & $0.56 \%(3)$ \\
S. uberis and CoNS & $1.48 \%(2)$ & $0 \%(0)$ \\
S. aureus and Streptococcus spp. & $0.74 \%(1)$ & $0.19 \%(1)$ \\
S. aureus and E. coli & $0.74 \%(1)$ & $0 \%(0)$ \\
S. aureus and Corynebacterium bovis & $0 \%(0)$ & $0.74 \%(4)$ \\
CoNS and Corynebacterium bovis & $0 \%(0)$ & $0.37 \%(2)$ \\
S. uberis and S. agalactiae & $0 \%(0)$ & $0.19 \%(1)$ \\
Contaminated & $5.18 \%(7)$ & $0.56 \%(3)$
\end{tabular}

Duplicate $^{\mathrm{b}}=$ the milk was regarded as bacteriologically positive if at least one of the duplicates was bacteriologically positive, regardless of which mastitis pathogen was isolated. S. aureus = Staphylococcus aureus; $S$. uberis $=$ Streptococcus uberis; CoPS = coagulase-positive staphylococci other than S. aureus; CoNS = coagulase-negative staphylococci; Streptococcus spp. = Streptococcus spp. excluding $S$. agalactiae, $S$. equinus, $S$. uberis, and Enterococcus sp.; S. agalactiae = Streptococcus agalactiae; $E$. coli $=$ Escherichia coli.

ms (DHI programs) over the last decades. For instance, the original SCC limit of a healthy quarter was 500,000 cells / $\mathrm{mL}$ (IDF 1971). Nevertheless, our findings on the sensitivity and specificity of lower SCC thresholds (i.e., 200,000 cells $/ \mathrm{mL}$ ) to diagnosis IMIs (Table 2) were similar to those previously reported (with a range from $73-89 \%$ and 75-90\%) (Schepers et al. 1997, Pyörälä 2003). Therefore, in recent years, a SCC limit of 100,000 cells/mL or lower has been suggested (Sargeant et al. 2001, Pyörälä 2003, 
Table 5. The ROC curve and sensitivity/specificity of composite SCC using composite and duplicate quarter milk bacteriological results as a gold standard test

\begin{tabular}{lcc}
\hline \multicolumn{1}{c}{ Predictive values/ } & Composite & Duplicate $^{\mathrm{b}}$ \\
\cline { 2 - 3 } Bacteriological sampling & Receiver operating characteristics (ROC) analysis \\
\hline Area under ROC curve $(95 \% \mathrm{CI})$ & $0.826(0.748-0.888)$ & $0.787(0.706-0.854)$ \\
P value & $<0.0001$ & $<0.0001$ \\
SCC Threshold (cells/mL) & 698,000 & 657,000 \\
Youden index & 0.536 & 0.472 \\
Sensitivity (95\% CI) & $65.7(53.1-76.8)$ & $61.7(50.3-72.3)$ \\
Specificity (95\% CI) & $87.9(76.7-95.0)$ & $85.4(72.2-93.9)$ \\
& \multicolumn{2}{c}{ Established threshold value } \\
200,000 cells/mL & $95.0(85.0-98.0)$ & $88.9(80.0-94.8)$ \\
Sensitivity $(95 \% \mathrm{CI})$ & \multicolumn{2}{|}{} \\
200,000 cells/mL & $36.2(24.0-49.9)$ & $37.5(24.0-52.6)$ \\
Specificity (95\% CI) & &
\end{tabular}

$\overline{\mathrm{ROC}}=$ receiver operating characteristics. Duplicate ${ }^{\mathrm{b}}=\mathrm{a}$ cow was regarded as bacteriologically positive if one or more quarter had a positive bacteriological result; a quarter was regarded as bacteriologically positive if at least one of the duplicates was bacteriologically positive, regardless of which mastitis pathogen was isolated. SCC = somatic cell count; 95\% CI = 95\% confidence interval.

Table 6. The median (mean + SEM) composite SCC (cells $/ \mathrm{mL}$ ) of the bacteriologically positive and negative milk samples

\begin{tabular}{lcc}
\hline Milk samples & Bacteriologically positive & Bacteriologically negative \\
\hline Composite $^{\text {Duplicate }}$ & $1,060,000(1,368,343+157,996)^{\mathrm{a}}$ & $273,000(413,793+65,950)^{\mathrm{b}}$ \\
Du $^{\mathrm{b}}$ & $855,000(1,235,074+140,440)^{\mathrm{a}}$ & $276,000(355,667+39,883)^{\mathrm{b}}$
\end{tabular}

Duplicate $^{b}=$ a cow was regarded as bacteriologically positive if one or more quarter had a positive bacteriological result; a quarter was regarded as bacteriologically positive if at least one of the duplicates was bacteriologically positive, regardless of which mastitis pathogen was isolated. SEM = standard error of the mean; SCC = somatic cell count. Different superscripts among the columns represent $\mathrm{P}<0.0001$

Table 7. The median (mean + SEM) composite milk SCC (cells $/ \mathrm{mL}$ ) in udders infected with different pathogens

\begin{tabular}{lcccc}
\hline $\begin{array}{l}\text { Bacteriological } \\
\text { composite results }\end{array}$ & CoNS & S. aureus & S. uberis & S. aureus and S. uberis \\
\hline SCC & 610,000 & $1,184,000$ & 517,500 & $1,902,000$ \\
& $(618,000+216,000)^{\mathrm{ac}}$ & $(1,262,000+184,514)^{\mathrm{ac}}$ & $(584,333+157,758)^{\mathrm{c}}$ & $(2,431,000+690,972)^{\mathrm{b}}$
\end{tabular}

$\overline{\mathrm{SEM}}=$ standard error of the mean; SCC = somatic cell count; CoNS = coagulase-negative staphylococci; . aureus = Staphylococcus aureus; S. uberis = Streptococcus uberis. Different superscripts among the columns represent $\mathrm{P}<0.05$.

Bansal et al. 2005, Schwarz et al. 2010). This decrease of the SCC limit to detect IMIs may be due to the presence of effective mastitis control programs in many developed countries, leading to a decrease in IMIs caused by major pathogens (i.e., S. agalactiae) and an increase in the proportion of IMIs caused by minor pathogens (i.e., coagulase-negative staphylococci) (Pitkälä et al. 2004, Piepers et al. 2007, Schwarz et al. 2010). Furthermore, the quarter milk SCC-derived incidence had a more limited predictive value in herds experiencing a very high rate of IMI acquisition during a given period (Dufour \& Dohoo 2013), which may have influenced our results, especially regarding the high bulk milk SCC in the herds used here, indicating that the cows are under high challenge (Barkema et al. 1998). Thus, estimates for the diagnostic sensitivity and specificity may vary in different populations due to the varying milk SCC thresholds used, and an epidemiological approa- ch in the target population should be used to validate the use of SCC as a diagnostic test (Pyörälä 2003).

Regarding the dynamic nature of the IMIs, our findings on subclinical mastitis (SCC $>200,000$ cells/mL) showed that $50.0 \%$ of the milk quarter samples with microbiologically negative outcomes (unspecific mastitis) resulted in no mastitis pathogen growth in subsequent sampling(s) (once monthly or every three weeks after the sampling with a microbiologically negative outcome and SCC $>200,000$ cells $/ \mathrm{mL}$ ) and a reduction in the milk quarter SCC (median $=529,834$ cells $/ \mathrm{mL}$ to 29,637 cells $/ \mathrm{mL}$; mean \pm standard error of the mean $(\mathrm{SEM})=1,147,637 \pm 442,637$ cells $/ \mathrm{mL}$ to $57,431 \pm 13,162$ cells $/ \mathrm{mL} ; P=0.0002$ ), indicating spontaneous microbiological cure of the IMIs (the ability of cows to self cure). Thus, SCC measurements and microbiological analysis over time will better distinguish among non-infected quarters, infection with subsequent self-cure, and 
Table 8. The diagnostic accuracy of the composite microbiology results compared with the bacteriological outcomes of the duplicate quarter milk samples, regarded as the gold standard

\begin{tabular}{lc}
\hline Sensitivity & $71.95 \%(60.94-81.32)$ \\
Specificity & $81.25 \%(67.37-91.05)$ \\
Area under ROC curve & $0.77(0.68-0.84)$ \\
Positive likelihood ratio & $3.84(2.10-7.02)$ \\
Negative likelihood ratio & $0.35(0.24-0.50)$ \\
Positive Predictive Value & $86.76 \%(76.36-93.77)$ \\
Negative Predictive Value & $62.90 \%(49.69-74.84)$
\end{tabular}

Results and 95\% confidence intervals are presented; ROC = receiver operating characteristics.

infection that is not cured by defense mechanisms. Consistent with our results, Pinzón-Sánchez \& Ruegg (2011) and Oliveira et al. (2013) have suggested that a lack of pathogen recovery in the microbiological analysis of milk samples from clinical mastitis cases of mastitis before initiating treatment indicates the outcome of the IMI after treatment. Thus, the no-growth mastitis pathogens from milk samples can also be related to the probability of a microbiological cure and indicate the low number of pathogens that are eliminated in milk and the reduced probability of isolating mastitis pathogens, as observed in our study. In other wor$\mathrm{ds}$, in these cases, the augmented milk SCC was effective in reducing the number of invading bacteria and consequently decreased the chance of isolating the causative pathogen, suggesting effective control of the infection by milk leukocytes. Hence, interpreting SCC data based on a single sampling is subject to possible misdiagnosis or misclassification.

We found a high SCC cut-off value (>500,000 cells/ $\mathrm{mL}$ ) and a relatively lower Youden index for composite samples by ROC curve analysis compared with individual quarter milk samples, highlighting the higher proportion of false-negative or false-positive results in composite SCCs. Thus, composite measurements of SCC for monitoring IMI incidence may be unreliable. Schukken et al. (2003) have reported that the most accurate relationship between IMI and SCC exists at the quarter level, which also supporting our findings. The predictive values of composite SCCs are dependent on the numbers of infected quarters and of pathogens involved in IMIs, as milk from infected quarters is diluted with normal milk from uninfected quarters (Reyher \& Dohoo 2011). Similarly, Reksen et al. (2008) reported that their accuracy was limited when the composite milk SCC was used to detect mastitis pathogens. Thus, the predictive values of composite milk samples should be considered; their use may be limited to the diagnosis of IMIs by identifying major pathogens (Dufour \& Dohoo 2013), although composite milk samples have great practical importance, especially regarding the costs of microbiological culture.

In the present study, the increase in milk SCCs varied among mastitis pathogens. Notably, the increase in the SCC is mainly dependent on the pathogenicity of the mastitis-causing bacteria and the amount of affected tissue in the gland, especially the affected epithelial area, which in turn can influence the predictive values of SCC used to diagnose mastitis (Pyörälä 2003). For instance, $C$. bovis did not result in a significant increase in milk SCC in this study. This pathogen has been regarded as a minor pathogen with limited clinical significance (Oliveira et al. 2013), probably due at least in part to the modulation of innate immunity (i.e., toll-like receptor 2) in an attempt to control inflammation and tissue injury (Blagitz et al. 2015). However, major pathogens, including S. aureus, S. agalactiae and Streptococcus uberis, led to a significant augmentation of the milk SCC in the present study, as previously described (Djabri et al. 2002, Souza et al. 2009, Botaro et al. 2015).

Our findings suggested that milk SCC and microbiological examinations, although regarded as the most reliable indicators of ongoing mastitis, should be used in an integrated manner in mastitis control programs. Furthermore, the accuracy and implications of single, duplicate and composite microbiological analyses to diagnosis mastitis should be considered in mastitis control programs.

Acknowledgements.- This study was supported by Conselho Nacional de Desenvolvimento Científico e Tecnológico (CNPq Projects 480102/20112 and 481950/2013-3) and Fundação de Amparo à Pesquisa do Estado de Minas Gerais (FAPEMIG Project APQ02210-13). The authors are also grateful to Guilherme A.C. Bartholomeu from GEPEC for his excellent technical assistance, and to Marcos A.S. Silva from EMBRAPA-Dairy Cattle Research Center for his excellent technical assistance with the milk cultures. FNS is indebted to CAPES (Coordenação de Aperfeiçoamento de Pessoal de Nível Superior) for his fellowship. AMMPDL, APL and MBH are indebted to CNPq for their fellowships. The authors also thank the contribution and support of the Laboratório de Análises da Qualidade do Leite of the Escola de Veterinária from Universidade Federal de Minas Gerais (LabUFMG).

Authors' contribution.- FNS participated in acquisition, analysis and interpretation of data, drafted and edited the manuscript. AFC, DLSOR, ASG and LCM participated in acquisition and analysis of data. MAVPB and GNS participated in the analysis and interpretation of data, study conception and design. MGB and APL gave technical support and conceptual advice, drafted, edited and critically revised the manuscript content. MMOPC, MBH and AMMPDL served as principal investigators, who designed the experiments, supervised studies, critically revised the manuscript and provided the final approval of the version to be published.

\section{REFERENCES}

Andersen S., Dohoo I.R., Riekerink O., Stryhn H. \& Mastitis Research Workers' Conference. 2010. Diagnosing intramammary infections: evaluating expert opinions on the definition of intramammary infections using conjoint analysis. J. Dairy Sci. 93:2966-2975.

Bansal B.K., Hamann J., Grabowskit N.T. \& Singh B. 2005. Variation in the composition of selected milk fraction samples from healthy and mastitic quarters, and its significance for mastitis diagnosis. J. Dairy Res. 72:144152.

Barkema H.W., Schukken Y.H., Lam T.J.G.M., Beiboer M.L., Wilmink H., Benedictus G. \& Brand A. 1998. Incidence of clinical mastitis in dairy herds grouped in three categories by bulk milk somatic cell counts. J. Dairy Sci. 81:411-419.

Blagitz M.G., Souza F.N., Batista C.F., Santos B.P., Parra A.C., Azevedo L.F.F. \& Della Libera A.M.M.P. 2015. Expression of CD14 and toll-like receptors 2 and 4 by milk neutrophils in bovine mammary glands infected with Corynebacterium bovis. Pesq. Vet. Bras. 35:1-5.

Botaro B.G., Cortinhas C.S., Dibbern A.G., Silva L.F., Benites N.R. \& dos Santos M.V. 2015. Staphylococcus aureus intramammary infection affects milk yield and SCC of dairy cows. Trop. An. Health Prod. 47:61-66.

Brito M.A.V.P., Brito J.R.F., Ribeiro M.T. \& Veiga V.M.O. 1999. Padrão de infecção intramamária em rebanhos leiteiros: exame de todos os quartos 
mamários das vacas em lactação. Arq. Bras. Med. Vet. Zootec. 51:129135.

Della Libera A.M.M.P., Souza F.N., Blagitz M.G. \& Batista C.F. 2011. Avaliação de indicadores inflamatórios no diagnóstico da mastite. Arqs Inst. Biológico, São Paulo, 78:297-300.

Djabri B., Bareille N., Beaudeau F. \& Seegers H. 2002. Quarter milk somatic cell count in infected dairy cows: a meta-analysis. Vet. Res. 33:334-357.

Dohoo I., Andersen S., Dingwell R., Hand K., Kelton D., Leslie K., Schukken Y. \& Godden S. 2011a. Diagnosing intramammary infections: comparison of multiple versus single quarter milk samples for the identification of intramammary infections in lactating dairy cows. J. Dairy Sci. 94:55155522.

Dohoo I.R., Smith J., Andersen S., Kelton D.F. \& Godden S. 2011b. Diagnosing intramammary infections: evaluation of definitions based on a single milk sample. J. Dairy Sci. 94:250-261.

Dufour S. \& Dohoo I.R. 2013. Monitoring herd incidence of intramammary infection in lactating cows using repeated longitudinal somatic cell count measurements. J. Dairy Sci. 96:1568-1580.

International Dairy Federation, 1971. A monograph of bovine mastitis.

Godden S.M., Jansen J.T., Leslie K.E., Smart N.L. \& Kelton D.F. 2002. The effect of sampling time and sample handling on the detection of Staphylococcus aureus in milk from quarters with subclinical mastitis. Can. Vet. J. 43:38-42.

Halasa T., Hujips K., Osteras O. \& Hogeveen H. 2007. Economic effects of bovine mastites and mastites management: a review. Vet. Quart. 29:18-31.

Keefe G. 1997. Streptococcus agalactiae mastitis: a review. Can. Vet. J. 38:429-437.

Koskinen M.T., Holopainen J., Pyörälä S., Bredbacka P., Pitkälä A., Barkema H.W., Bexiga R., Roberson J., Solverod L., Piccinini R., Kelton D., Lehmusto H., Niskala S. \& Salmikivi L. 2009. Analytical specificity and sensitivity of a real-time polymerase chain reaction assay for identification of bovine mastitis pathogens. J. Dairy Sci. 92:952-959.

Makovec J.A. \& Ruegg P.L. 2003. Results of milk samples submitted for microbiological examination in Wiscosin from 1994 to 2000. J. Dairy Sci. 86:3466-3472.

Nunes G.R., Blagitz M.G., Batista C.F., Souza F.N., Ricciardi M., Stricagnolo C.R., Sanches B.G.S., Azedo M.R., Sucupira M.C.A. \& Della Libera A.M.M.P. 2008. Avaliação de indicadores inflamatórios no diagnóstico da mastite ovina. Arqs Inst. Biológico, São Paulo, 75:271-278.

Oliver S.P., Lewis M.J., Gillespie B.E., Dowlen H.H., Jaenicke E.C. \& Roberts R.K. 2004. Microbiological Procedures for the Diagnosis of Bovine Udder Infection and Determination of Milk Quality. 4th ed. National Mastitis Council, Verona. 47p.

Oliveira L., Huland C. \& Ruegg P.L. 2013. Characterization of clinical mastitis occurring in cows on 50 large dairy herds in Wiscosin. J. Dairy Sci. 96:7538-7549.

Piepers S., De Meulemeester L., De Kruif A., Opsomer G., Bakema H.W. \& De Vliegher S. 2007. Prevalence and distribution of mastitis pathogens in subclinically infected dairy cows in Flanders, Belgium. J. Dairy Res. 74:478-483.

Pinzón-Sánchez C. \& Ruegg P.L. 2011. Risk factors associated with short-term post-treatment outcomes of clinical mastitis. J. Dairy Sci. 94:33973410.

Pitkälä A., Haveri M., Pyörälä S., Myllys V. \& Honkanen-Bulzalski T. 2004. Bovine mastitis in Finland 2001 - Prevalence, distribution of bacteria, and antimicrobial resistance. J. Dairy Sci. 87:2433-2441.

Pyörälä S. 2003. Indicators of inflammation in the diagnosis of mastitis. Vet. Res. 34:565-578.

Reksen O., Solverod L. \& Osteras 0. 2008. Relationship between milk culture results and composite milk somatic counts in Norwegian dairy cattle. J. Dairy Sci. 91:3102-3113.

Reyher K.K. \& Dohoo I.R. 2011. Diagnosing intramammary infections: evaluation of composite milk samples to detect intramammary infections. J. Dairy Sci. 94:3387-3396.

Ruegg P.L. \& Pantoja J.C.F. 2013. Understading and using somatic cell counts to improve milk quality. Irish J. Agricult. Food Res. 52:101-117.

Sargeant J.M., Leslie K.E., Shirley J.E., Pulkrabek B.J. \& Lim G.H. 2001. Sensitivity and specificity of somatic cell count and California mastitis test for identifying intramammary infection in early lactation. J. Dairy Sci. 84:2018-2014.

Schepers A.J., Lam T.J., Schukken Y.H., Wilmink J.B. \& Hanekamp W.J. 1997. Estimation of variance components for somatic cell counts to determine thresholds for uninfected quarters. J. Dairy Sci. 80:1833-1840.

Schisterman E.F., Perkins N.J., Liu A. \& Bondell H. 2005. Optimal cut-off and its corresponding Younden index to discriminate individuals using pooled blood samples. Epidemiology 16:73-81.

Schukken Y.H., Wilson D.J., Welcome F., Garrison-Tikofsky L. \& Gonzalez R.N. 2003. Monitoring udder health and milk quality using somatic cell counts. Vet. Res. 34:579-596.

Schwarz D., Diesterbeck K., Failing K., König S., Brügemann K., Zschöck M., Wolter W. \& Czerny C.P. 2010. Somatic cell count and microbiological status in quarter foremilk samples of cows in Heese, Germany - A longitudinal study. J. Dairy Sci. 93:5716-5728.

Sears P.M., Smith B.S., English P.B., Herer P.S. \& Gonzalez R.N. 1990. Shedding pattern of Staphylococcus aureus from bovine intramammary infections. J. Dairy Sci. 73:2785-2789.

Souza G.N., Moreira E.C., Brito J.R.F., Brito M.A.V.P. \& Silva M.V.G.B. 2009. Variação da contagem de células somáticas em vacas leiteiras de acordo com patógenos da mastite. Arq. Bras. Med. Vet. Zootec. 61:1015-1020.

Walker J.B., Rajala-Schultz P.J. \& DeGraves F.J. 2010. The effect of inoculum volume on the microbiologic detection of naturally occurring Staphylococcus aureus intramammary infections. J. Vet. Diagn. Invest. 22:720724.

Zecconi A., Piccinini R., Zepponi A. \& Ruffo G. 1997. Recovery of Staphylococcus aureus from centrifuged quarter milk samples. J. Dairy Sci. 80:3858-3863. 